\title{
Records of corticolous myxomycetes from selected trees in Angat Watershed Forest Reserve, Bulacan, Philippines
}

\author{
Monica S. Policina ${ }^{1,3}$ and Thomas Edison E. dela Cruz ${ }^{1,2,3} *$
}

\begin{abstract}
Corticolous myxomycetes are a specialized guild of myxomycetes thriving on the bark of living trees. In this study, we explored the bark-inhabiting myxomycetes from selected trees in the Angat Watershed Forest Reserve, Bulacan, Philippines. Pieces of dead tree barks were carefully removed from selected mature trees - Gmelina arborea ("gmelina" or "yemane"), Mangifera indica ("mango"), Parkia timoriana ("kupang"), Pinus sp. ("pine tree"), Pterocarpus indicus ("narra"), Samanea saman ("acacia" or "rain tree"), and Shorea contorta ("white lauan"), within the accessible forest area and used for the preparation of moist chamber culture. Following incubation for 8-12 weeks, fruiting bodies from the moist chambers were identified. Results showed a total of 17 species belonging to 10 genera from five orders. The identified corticolous myxomycetes were Arcyria cinerea, A. denudata, Comatricha pulchella, C. tenerrima, Cribraria microcarpa, C. violacea, Diderma effusum, D. hemisphaericum, Hemitrichia pardina, Lamproderma scintillans, Licea operculata, Licea sp.1, Perichaena chrysosperma, P. pedata, Physarum album, P. leucophaeum, and Trichia decipiens. This is the first report of corticolous myxomycetes in the Angat Watershed Forest Reserve.
\end{abstract}

Keywords: bark, moist chamber culture, Paleotropics, plasmodial slime molds, species list

\section{Introduction}

One of the substrates suitable for the growth of myxomycetes or plasmodial slime molds is the bark surface of living trees. A specialized guild of myxomycetes, the corticolous myxomycetes, is known to inhabit this microhabitat in trees as well as vines (Everhart \& Keller 2008). Unfortunately, they have received little attention because most species possess minute fruiting bodies, which make it very difficult to be observed in nature with an unaided eye (Novozhilov et al. 2017). However, this group gradually becomes the subject of numerous studies using moist chamber technique. This method can reliably detect these myxomycetes and subsequently reveal a whole assemblage of species

\footnotetext{
${ }^{1}$ The Graduate School, ${ }^{2}$ Department of Biological Sciences, College of Science, and ${ }^{3}$ Fungal Biodiversity, Ecogenomics and Systematics (FBeS) Group, Research Center for the Natural and Applied Sciences, University of Santo Tomas, España Blvd. 1008 Manila, Philippines

*Corresponding email: tedelacruz@ust.edu.ph

Date Submitted: 01 May 2020

Date Accepted: 07 October 2020
}

associated with the tree bark surface (Snell \& Keller 2003). The bark $\mathrm{pH}$ is reported to have a significant influence on the occurrence of these myxomycetes (Everhart et al. 2009). Some species occur only at specific $\mathrm{pH}$ ranges while others are found over a broad pH range (Snell \& Keller 2003; Everhart et al. 2008). However, other factors such as the bark texture, epiphytic cover, and water holding capacity also showed varying effects on the occurrence and abundance of corticolous myxomycetes (Stephenson 1989; Snell \& Keller 2003; Schnittler et al. 2006).

Currently, ca. 120 species of corticolous myxomycetes has been recorded from bark microhabitats (Mitchell 2004). Some prominent species belong to the genera Echinostelium and Licea. Members of this group possessed protoplasmodia or aphanoplasmodia and their fruiting bodies develop rapidly on the bark (Mitchell 2004; Novozhilov et al. 2017). Some corticolous species may have restricted occurrence on the bark surface of living trees while other corticolous species also occur in other microhabitats such as soil, leaf litter, and twigs. Novozhilov et al. (2017) believed that this group of myxomycetes are more specialized than others.

Studies on corticolous myxomycetes in tropical countries are rather limited. In the Philippines, Dagamac et al. (2010) initiated a study on corticolous myxomycetes associated with 
Samanea saman (Jacqs.) Merr., or commonly known as "acacia", from different sites in Luzon Island. Their results identified seven species of myxomycetes, namely, Arcyria cinerea (Bull.) Pers., Clastoderma microcarpum (Meyl.) Kowalski, Dianema harveyi Rex, Diderma subasteroides M.L. Farr, Physarum album (Bull.) Chevall., P. leucophaeum Fr. \& Palmquist, and Stemonitis pallida Wingate, five of which were new records for the country. Since little progress has been made on corticolous myxomycetes in the Philippines, we conducted this study to document the occurrence of myxomycetes associated with the barks of living trees within the Angat Watershed Forest Reserve in Bulacan, Philippines.

\section{Materials and Methods}

\section{Study area and sampling}

Angat Watershed Forest Reserve $\left(14.90201^{\circ} \mathrm{N}\right.$, $121.15344^{\circ} \mathrm{E}$ ) is a protected landscape located at the southernmost portion of the Sierra Madre mountain range. It is bordered by the municipalities of Doña Remedios Trinidad, Norzagaray, and San Jose Del Monte in the province of Bulacan, Luzon Island. It is characterized by hilly to mountainous terrain with lowland forests often dominated by dipterocarps. Degradation is evident in most parts of the accessible forests. The climate falls under Type I climate and is characterized with two pronounced seasons: dry season from November to April and wet season during the rest of the year. In this study, trees were randomly selected in six sampling points:

(1) forest near the Angat Watershed Area Team (AWAT) Office, (2) the Tariktik trail, (3) Spillway, (4) Babuyan, (5) Lower Camp, and (6) Bininit (Fig. 1). Gratuitous permit was secured from the National Power Corporation (NAPOCOR) prior to collection.

\section{Collection of bark substrates and preparation of moist chamber cultures}

The field expedition was carried out from late August to mid-September 2019. Bark substrata were sampled from 34 mature trees, identified as Gmelina arborea Roxb. ex Sm. ("gmelina" or "yemane", 2 trees), Mangifera indica L. ("mango", 2 trees), Parkia timoriana (DC.) Merr. ("kupang", 1 tree), Pinus sp. ("pine tree", 5 trees), Pterocarpus indicus Willd. ("narra", 5 trees), Samanea saman (Jacqs.) Merr. ("acacia" or "rain tree", 13 trees), and Shorea contorta Vidal ("white lauan", 6 trees). The trees were selected via opportunistic sampling strategy. From the selected living trees, 10-20 pieces of barks were carefully removed from the north-, east-, west-, and southfacing sides of the trunk at $1.2-1.5 \mathrm{~m}$ above the ground in order to exclude the soil-inhabiting myxomycetes. Barks collected in

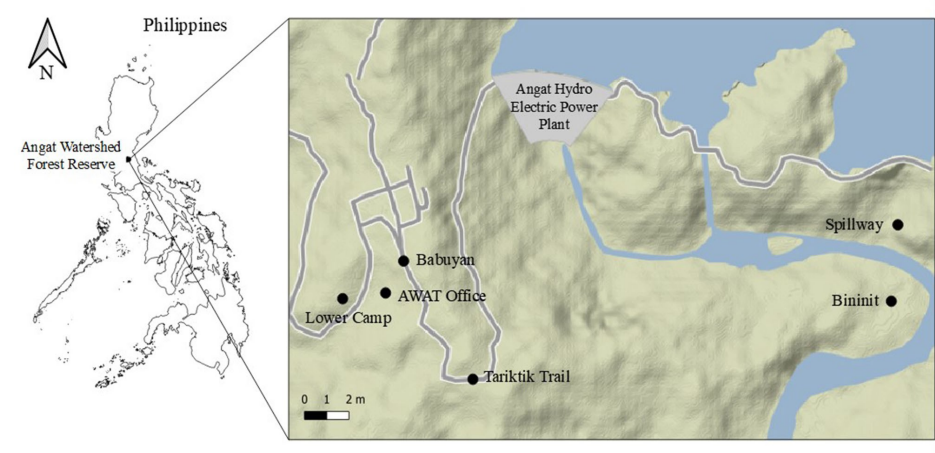

Figure 1. Map of the sampling area: Angat Watershed Forest Reserve, Bulacan Province, Northern Philippines (map generated using QGIS 3.12.2).

each direction from a host tree were separately placed inside brown paper bags and thus, were treated as technical replicates. The bags were then transported to the laboratory and allowed to air-dry for a week prior to the preparation of moist chamber cultures. Afterward, moist chambers (MC, one per bark samples resulting in a total of $136 \mathrm{MCs}$ ) were prepared following the protocol described by Stephenson \& Stempen (1994). Briefly, bark samples were cut to at least $20 \mathrm{~mm}$ size pieces. Three-five pieces of bark samples were placed evenly, with the outer surface of the bark facing upward, in the Petri dishes (diameter $=90 \mathrm{~mm}$ ) lined with filter paper and later were covered with its lid. Samples were flooded with distilled water and soaked overnight. After $24 \mathrm{~h}$, each MC was tested for $\mathrm{pH}$ level and then the surplus water was drained, leaving enough water to keep the filter paper moist. Afterward, the MCs were placed in a multilayer, open-shelf, wooden cabinet, incubated at room temperature $\left(24-26{ }^{\circ} \mathrm{C}\right)$ under diffused light, and examined regularly (at least thrice a week) for any presence of myxomycetes under stereomicroscope (Olympus SZ61-ILST) for a span of 8-12 weeks. A small amount of water was occasionally added in the MCs to prevent the complete drying of the moist chambers.

\section{Characterization and Identification of Myxomycetes}

All identifiable fruiting bodies obtained from the MC cultures were glued inside herbarium boxes and deposited in the Myxomycete Collection (USTMC) of the Mycology Laboratory, Research Center for the Natural and Applied Sciences, University of Santo Tomas, Manila. Photos were captured using DSLR camera (Canon 80D). Morphological characters of the fruiting bodies, i.e., type, shape, color, including other special features such as the presence of $\mathrm{CaCO}_{3}$ deposits, capillitum, or columella, were observed. Identification of the fructifications and nomenclature were based on published literature and webbased identification keys (Mitchell 2004; Lado 2005-2020; 
Lloyd 2020).

\section{Analysis of the sampling effort and abundance}

Since the current study provides baseline data on the assessment of corticolous myxomycetes in the Angat Watershed Reserve Forest, the exhaustiveness of the sampling effort survey was evaluated by computing the species accumulation curve (SAC) for the records of all trees based on Chaol estimator using the program EstimateS 9.1.0 (Colwell 2013). Relative abundance was also determined by dividing the total number of collections of each species by the total number of myxomycetes collected multiplied by 100 (Stephenson et al. 1993). Here, a moist chamber that is positive for a myxomycete is considered as one collection for that species. Given the lower number of records (43 collections) in this study as opposed to the very high number of records $(3,788$ collections) in Stephenson et al. (1993), we opted to use the Abundance Index (AI) developed by Dagamac et al. (2012) which was based from 159 records. Thus, AI values are $\mathrm{R}=$ rare, if the number of specimens (abundance) of a particular species is $<3 \%$ of the total number of collections, $\mathrm{O}=$ occasional, if the abundance is $\geq 3 \%$ but $<5 \%$ of the total number of collections, $\mathrm{C}=$ common, if the abundance is $\geq 5 \%$ but $<10 \%$ of the total number of collections, and $\mathrm{A}=$ abundant, if the abundance is $\geq 10 \%$ of the total number of collections.

\section{Results}

Of the 136 moist chambers (MCs) prepared with bark samples, a total of $73 \mathrm{MCs}(=54 \%)$ yielded positive evidence of myxomycetes, either as fruiting bodies or as plasmodia, from which 36 MCs positive with plasmodia did not develop into fruiting bodies. Seventeen species of corticolous myxomycetes belonging to 10 genera and 5 orders were identified in this study. One unidentified Licea sp. 1 with collection codes USTMC 2914, USTMC 2915, and USTMC 2916 is suspected to be a new species but needs further investigation. In the following list, myxomycetes are arranged alphabetically with the UST Myxomycete Collection (USTMC) specimen codes and grouped by taxonomic orders of the species following Leontyev et al. (2019). The total number of collections equivalent to the number of MCs where the species were recorded and the corresponding AI are presented as [number, $\mathrm{AI}$ ]. The number of collections per host tree in parenthesis (number) and the $\mathrm{pH}$ of the bark samples were also indicated. We included observations for some species.

\section{Annotated list of species}

\section{Cribrariales}

Cribraria microcarpa (Schrad.) Pers. (USTMC 2908)

[8 collections, A]: tree host/s: mango tree ( 3$)$ at mean bark $\mathrm{pH}=$ $6.88 \pm 0.30$, pine tree (2) at mean bark $\mathrm{pH}=6.38 \pm 0.02$, and white lauan (3) at mean bark $\mathrm{pH}=5.02 \pm 0.09$.

Cribraria violacea $\mathrm{Rex}$ (USTMC 2911)

[1 collection, R]: tree host/s: acacia (1) at bark pH 6.27.

\section{Liceales}

Licea operculata (Wingate) G.W. Martin (USTMC 2912, USTMC 2913, USTMC 2914)

[2 collections, O]: tree host/s: acacia (2), at mean bark $\mathrm{pH}=6.00$ \pm 0.38 .

Licea sp. 1 (Fig. 3) (USTMC 2914, USTMC 2915, USTMC 2916)

[3 collections, C]: tree host/s: acacia (3), at mean bark $\mathrm{pH}=7.38$ \pm 0.69 .

Sporocarps sessile or subsessile. Sporotheca globulose, orange. Peridium forming dark patches when matured. Capilitium light colored, scarce. Spores free, lightly colored, smooth or minutely warted. Fructifications resembled Perichaena corticalis, but the scarce to no capilitium is a defining character for species of Licea. Likewise, it is distinct from the other Licea species with its sporangia markedly globose, even viewed from the top unlike L. marginata, and spores free with evenly thin walls and smooth on all sides, in contrast with $L$. synsporos. Possibly a new species but requires more detailed characterization, specifically on spore surface structures and ornamentation under scanning electron microscope (SEM).

\section{Physarales}

Diderma effusum (Schwein.) Morgan (USTMC 2917)

[2 collections, O]: tree host/s: pine tree (2), at mean bark $\mathrm{pH}=$ $5.59 \pm 0.30$.

Diderma hemisphaericum (Bull.) Hornem. (USTMC 2918)

[1 collection, R]: tree host/s: mango tree (1), at bark $\mathrm{pH}=7.20$.

Physarum album (Bull.) Chevall. (USTMC 2919, USTMC 2920)

[ 3 collections, $\mathrm{C}$ ]: tree host/s: acacia (2) at mean bark $\mathrm{pH}=6.29$ \pm 0.30 , white lauan (1), at bark $\mathrm{pH}=5.50$.

Physarum leucophaeum Fr. \& Palmquist (USTMC 2921, USTMC 2922)

[7 collections, A]: tree host/s: acacia (6) at mean bark $\mathrm{pH}=6.33$ \pm 0.43 , white lauan (1) at bark $\mathrm{pH}=6.07$. 


\section{Stemonitidales}

Comatricha pulchella (C. Bab.) Rostaf. (USTMC 2923)

[2 collections, O]: tree host/s: acacia (2), at mean bark $\mathrm{pH}=$ $6.83 \pm 0.79$.

Comatricha tenerrima (M.A. Curtis) G. Lister (USTMC 2924)

[1 collection, $\mathrm{R}]$ : tree host/s: narra (1), at bark $\mathrm{pH}=6.99$.

Lamproderma scintillans (Berk. \& Broome) Morgan (USTMC 2925)

[1 collection, $\mathrm{R}]$ : tree host/s: narra (1), at bark $\mathrm{pH}=6.99$.

\section{Trichiales}

Arcyria cinerea (Bull.) Pers. (USTMC 2926, USTMC 2927)

[2 collections, O]: tree host/s: gmelina (1) at bark $\mathrm{pH}=9.17$, pine tree (1) at bark $\mathrm{pH}=5.70$.

Arcyria denudata (L.) Wettst. (USTMC 2928)

[1 collection, $\mathrm{R}]$ : tree host/s: pine tree (1), at bark $\mathrm{pH}=5.23$.

Hemitrichia pardina (Minakata) Ing (USTMC 2929, USTMC 2930, USTMC 2931)

[4 collections, $\mathrm{C}$ ]: tree host/s: acacia (2) at mean bark $\mathrm{pH}=7.32$ \pm 0.11 , mango (1) at bark $\mathrm{pH}=7.20$, narra (1) at bark $\mathrm{pH}=$ 6.99 .

Perichaena chrysosperma (Curr.) Lister (USTMC 2932, USTMC 2933)

[2 collections, O]: tree host/s: acacia (1) at bark $\mathrm{pH}=6.57$, pine tree (1) at bark $\mathrm{pH}=5.80$.

Perichaena pedata (Lister \& G. Lister) G. Lister ex E. Jahn (USTMC 2934)

[1 collection, $\mathrm{R}]$ tree host/s: white lauan (1) at bark $\mathrm{pH}=6.17$.

Trichia decipiens (Pers.) T. Macbr. (USTMC 2935, USTMC 2936)

[2 collections, O] tree host/s: acacia (1) at bark $\mathrm{pH}=4.85$, narra

(1) at bark $\mathrm{pH}=6.57$

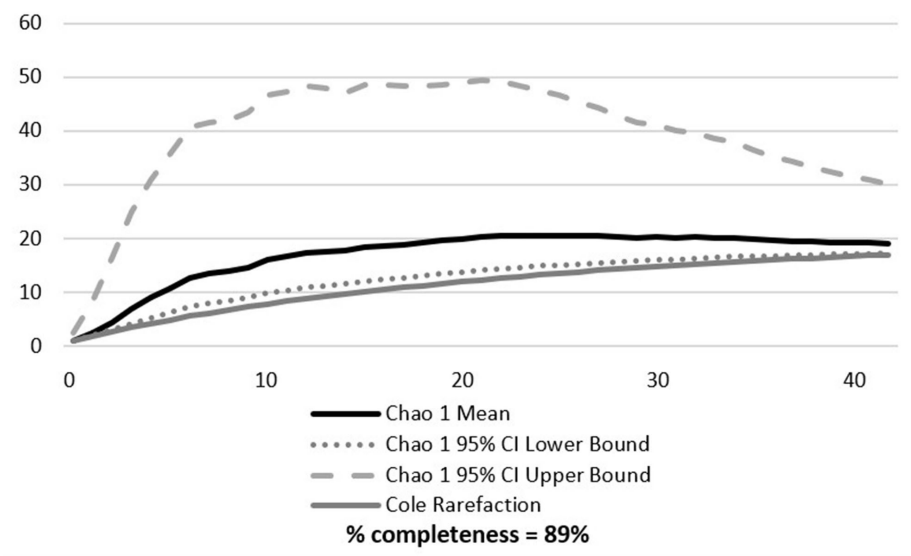

Figure 2. Species accumulation curve showing sampling effort expressed as percent completeness for corticolous myxomycetes in Angat Watershed Forest Reserve.

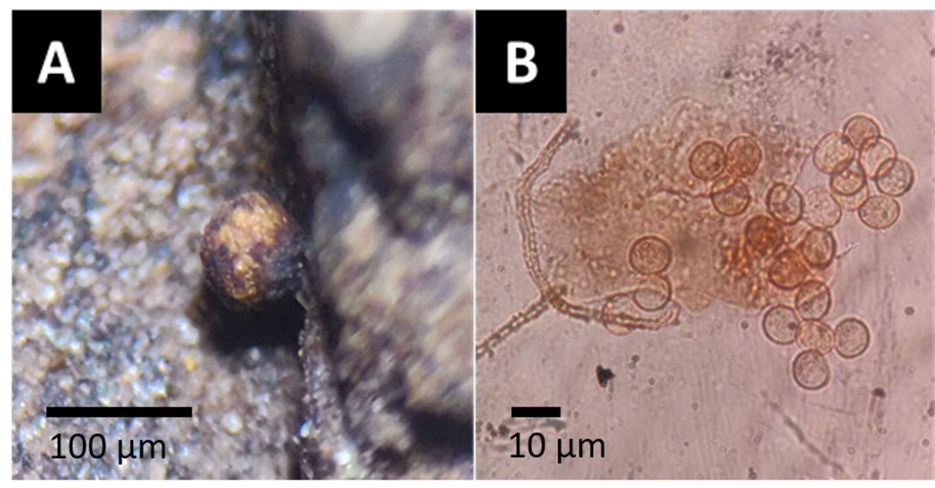

Figure 3. New records of corticolous myxomycetes collected in Angat Watershed Forest Reserve, possibly new Licea species (a-sporocarp, b -spores).

\section{Discussion}

In this study, a relatively low myxomycete yield ( $=54 \%)$ was observed from the barks collected in 34 mature trees. This is expected when using moist chamber culture technique for a specialized guild of myxomycetes such as corticolous myxomycetes and has been observed even with other specialized substrata (Liu et al. 2015). Among the tree hosts, Samanea saman had nine species of myxomycetes, followed by Pinus sp. with 5 species, then by Pterocarpus indicus and Shorea contorta with 4 species each, Mangifera indica with 3 species, and Gmelina arborea with 1 species. This could be attributed to the number of collected barks as we did not observe any tree host specificity. As the number of bark samples increased, the number of collected myxomycetes also increased. For example, S. saman had 52 bark samples or MCs and had nine identified species. In contrast, $P$. indicus, $S$. contorta, and Pinus sp. yielded $4-5$ species from 24 moist chambers. No myxomycetes were recorded from bark samples of Parkia timoriana. However, our species accumulation curve showed computed percent completeness of $89 \%$ (Fig. 2), indicating that we were able to collect most species of expected corticolous myxomycetes. We also recorded a total of 43 records of fructifications or collections. Given this low number of records for corticolous myxomycetes, we used the Abundance Index (AI) developed by Dagamac et al. (2012). Hence, in this study, we recorded 2 abundant species (A), 3 commonly occurring species $(\mathrm{C}), 6$ occasionally occurring species $(\mathrm{O})$, and 6 rare species (R). We proposed the AI values of Dagamac et al. (2012) for special guilds of myxomycetes such as corticolous myxomycetes and/or for microhabitats that support a low number of myxomycetes, e.g. barks, dung, etc.

Most of the species listed here are considered cosmopolitan species. These species, i.e., Arcyria cinerea, A. denudata, Comatricha pulchella, C. tenerrima, Cribaria 
microcarpa, Diderma effusum, D. hemisphaericum, Lamproderma scintillans, Perichaena chrysosperma, P. pedata, and Trichia decipiens, were already reported from some parts of the Philippines, albeit from leaf litter and twigs (dela Cruz et al. 2010, Dagamac et al. 2011, 2017, Corpuz et al. 2012, Macabago et al. 2012, Kuhn et al. 2013, Alfaro et al. 2014, Viray et al. 2014, Rea-Maminta et al. 2015, Pecundo et al. 2017, Almadrones-Reyes \& Dagamac 2018, Bernardo et al. 2018). Interestingly, $A$. cinerea and $C$. violacea are said to be abundant in bark substrates in temperate regions (Everhart et al. 2009), both of which were present in this study. Likewise, A. cinerea and certain Physarum species such as Physarum album and $P$. leucophaeum were also reported as corticolous species associated with Samanea saman in the study of Dagamac et al. (2010). Licea operculata has only been recorded from twigs in Mt. Palay Palay National Park in the province of Cavite (dela Cruz et al. 2014). All species listed in this study have previously been recorded in the Philippines (Dagamac \& dela Cruz 2015, 2019) except for one possible new species of Licea that can be identified only up to the genus level. This annotated list served as the first report of corticolous myxomycetes in Angat Watershed Forest Reserve and increased the number of recorded corticolous myxomycetes in the Philippines to 21 . It also reveals that the bark microhabitat from tropical trees can harbor many diverse assemblages of myxomycetes. This study is so far the most extensive species listing of bark-associated myxomycetes in the country.

\section{Acknowledgement}

The study was funded in part by the scholarship and thesis grant from Department of Science and Technology Accelerated Science and Technology Human Resource Development Program (DOST ASTHRDP) to the first author and by the research grant from the UST Research Center for the Natural and Applied Sciences (RCNAS). The authors would also like to express their gratitude to N.H.A Dagamac for verifying the identification of the specimens and the RCNAS for the use of facilities. Utmost acknowledgment is also extended to National Power Corporation (NAPOCOR) for granting us the gratuitous permit to conduct our study in Angat Watershed Forest Reserve and the Angat Watershed Area Team for the assistance during the collection of the bark samples.

\section{Literature Cited}

Alfaro, J.R.D., D.L.I.M. Alcayde, J.B. Agbulos, N.H.A. Dagamac \& T.E.E. dela Cruz, 2014. The occurrence of myxomycetes from a lowland montane forest and agricultural plantations of Negros Occidental, Western Visayas, Philippines. FineFocus, 1: 7-20.

Almadrones-Reyes, K. \& N. Dagamac, 2018. Predicting local habitat suitability in changing climate scenarios: Applying species distribution modelling for Diderma hemisphaericum. Current Research in Environmental \& Applied Mycology, 8: 492-500.

Bernardo, J., L. Arioder, K. Almadrones-Reyes \& N. Dagamac, 2018. Myxomycete communities occurring in fragmented forest patches in two municipalities of Laguna, Philippines. Community Ecology, 19: 289-299.

Colwell, R.K., 2013. EstimateS: Statistical estimation of species richness and shared species from samples. Version 9 and earlier. User's Guide and application. Available at: http:// purl. oclc. org/estimates.

Corpuz, I.R., C.C. Martinez, K. Petilla, J. Baranda, A. Buaya \& T.E.E. dela Cruz, 2012. Occurrence and diversity of myxomycetes (plasmodial slime molds) in Mt. Palay-palay National Park, Cavite, Philippines. Acta Manilana, 60: 5765.

Dagamac, N.H.A., D. Leontyev \& T.E.E. dela Cruz, 2010. Corticolous myxomycetes associated with Samanea samans (Jacq.) Merr. collected from different sites in Luzon Island, Philippines. The Philippine Biota, 43: 2-15.

Dagamac, N.H.A., T.E.E. dela Cruz, M.V.B. Pangilinan \& S.L. Stephenson, 2011. List of species collected and interactive database of myxomycetes (plasmodial slime molds) for Mt. Arayat National Park, Pampanga, Philippines. Mycosphere, 2: 449-455.

Dagamac, N.H.A., Stephenson S.L., \& dela Cruz, T.E.E. 2012. Occurrence, distribution and diversity of myxomycetes (plasmodial slime moulds) along two transects in Mt. Arayat National Park, Pampanga, Philippines. Mycology, 3:119-126.

Dagamac, N.H.A. \& T.E.E. dela Cruz, 2015. Myxomycete research in the Philippines: Updates and opportunities. Mycosphere, 6: 784-795.

Dagamac, N.H.A., T.E.E. dela Cruz, M.A.D. Rea-Maminta, J.V. Aril-dela Cruz \& M. Schnittler, 2017. Rapid assessment of myxomycete diversity in the Bicol Peninsula, Philippines. Nova Hedwigia, 104: 31-46.

Dagamac, N.H.A. \& T.E.E. dela Cruz, 2019. The Philippine slime molds after Dogma's 1975 list - How far have we been? Philippine Journal of Systematic Biology, 13(2): 5865.

dela Cruz, T.E.E., M.A.D. Rea, H.T.M. Tran, T.W. Ko Ko \& S.L. Stephenson, 2014. A comparative species listing of myxomycetes from tropical (Philippines) and temperate (United States) forests. Mycosphere, 5(2): 299-311. 
dela Cruz, T.E.E., M.V.B. Pangilinan, R.J. Cruz, E.E. de Jesus, R.G. Puylong \& N.H.A. Dagamac, 2010. A checklist of plasmodial myxomycetes (slime molds) from Subic Watershed Forest Reserve, Zambales, Philippines. Acta Manilana, 58: 41-45.

Everhart, S.E., J.S. Ely \& H.W. Keller, 2009. Evaluation of tree canopy epiphytes and bark characteristics associated with the presence of corticolous myxomycetes. Botany, 87: 509517.

Everhart, S.E. \& H.W. Keller, 2008. Life history strategies of corticolous myxomycetes: the life cycle, plasmodial types, fruiting bodies, and taxonomic orders. Fungal Diversity, 29: 1-16.

Everhart, S.E., H.W. Keller \& J.S. Ely, 2008. Influence of bark $\mathrm{pH}$ on the occurrence and distribution of tree canopy myxomycete species. Mycologia, 100: 191-204.

Kuhn, R.V., A.O.M. Javier, C.P. Rodillas, C.M. Parra, L.H.M. Corpuz, L.S. Moron \& T.E.E. dela Cruz, 2013. Occurrence and distribution of myxomycetes (plasmodial slime molds) in three provinces of Luzon Island, Philippines. Philippine Science Letters, 6(1): 1-7.

Lado, C., 2005-2020. An on-line nomenclatural information system of Eumycezotozoa. Real Jardin Botanico, CSIS. Madrid, Spain. Available at: http:// www.nomen.eumycetozoa.com.

Leontyev, D.V., M. Schnittler, S.L. Stephenson, Y.K. Novozhilov \& O.N. Shchepin, 2019. Towards a phylogenetic classification of the Myxomycetes. Phytotaxa, 399: 209-238.

Liu, Q., S. Yan, \& S. Chen, 2015. Species diversity of myxomycetes associated with different terrestrial ecosystems, substrata (microhabitats) and environmental factors. Mycological Progress, 14: 1-13.

Lloyd, S.J., 2020. Myxomycetes at Black Sugarloaf Tasmania, Australia. Tympanocryptis Press, Tasmania, Australia.

Macabago, S.A.B., T.E.E. dela Cruz \& S.L. Stephenson, 2012. First records of myxomycetes from Lubang Island, occidental Mindoro, Philippines. Sydowia, 64: 109-118.

Mitchell, D.W., 2004. A key to corticolous Myxomycota. Systematics and Geography of Plants, 74: 261-285.

Novozhilov, Y.K., A.W. Rollins \& M. Schnittler, 2017. Ecology and distribution of Myxomycetes. In: Stephenson, S.L. \& C. Rojas, (ed.), Myxomycetes: Biology, Systematics, Biogeography and Ecology. Academic Press, London. pp. 253-297.

Pecundo, M.H., N.H.A. Dagamac, S.L. Stephenson \& T.E.E. Dela Cruz, 2017. First myxomycete survey in the limestone forest of Puerto Princesa Subterranean River National Park, Palawan, Philippines. Nova Hedwigia, 104: 129-141.
Rea-Maminta, M., N. Dagamac, F. Huyop, R. Wahab \& T. dela Cruz, 2015. Comparative diversity and heavy metal biosorption of myxomycetes from forest patches on ultramafic and volcanic soils. Chemistry and Ecology, 31: 741-753.

Schnittler, M., M. Unterseher \& J. Tesmer, 2006. Species richness and ecological characterization of myxomycetes and myxomycete-like organisms in the canopy of a temperate deciduous forest. Mycologia, 98: 223-232.

Snell, K.L. \& H.W. Keller, 2003. Vertical distribution and assemblages of corticolous myxomycetes on five tree species in the Great Smoky Mountains National Park. Mycologia, 95: 565-576.

Stephenson, S.L., 1989. Distribution and ecology of myxomycetes in temperate forests. II. Patterns of occurrence on bark surface of living trees, leaf litter, and dung. Mycologia, 81: 608-621.

Stephenson, S.L., I. Kalyanasundaram \& T.N. Lakhanpal, 1993. A comparative biogeographical study of myxomycetes in the mid-Appalachians of eastern North America and two regions of India. Journal of Biogeography, 20 (6): 645-657.

Stephenson, S.L. \& H. Stempen, 1994. Myxomycetes: A Handbook of Slime Molds. Timber Press, Portland, Oregon, USA.

Viray, A.T., D.D.S. Rotap, L.L. Migraso, N.C.I. Sibbaluca, E.C.V. Escobar, A.T. Buaya \& T.E.E. dela Cruz, 2014. Occurrence and diversity of myxomycetes (slime molds) in Polillo Island, Quezon Province, Philippines. Acta Manilana, 62: 9-17. 